\title{
The Effect of Two-Dimensional Learning Style on Interactive Multimedia Learning to the Learning Result
}

\author{
Muhammad Rusli \\ STMIK-STIKOM Bali \\ Raya Puputan 86, Renon, \\ Denpasar, Indonesia
}

\begin{abstract}
In the learning process, there are some elements that have to be noticed in order to make it effective and optimal. The elements are; the objective of the learning process, the type of content, the learning method, the delivery media, and the learning style of the students. The focus of this research was the learning style of the students, in the learning context with interactive multimedia (animation) which was needed to be accommodated, since that one of the characteristics of multimedia learning which was developed to create selflearning. This research aims to investigate the effect of those different two-dimensional learning style (input [visual vs verbal] and understand [sequential vs global]) on the computer based interactive multimedia learning to the learning result. The learning process with multimedia learning was conducted in a class with the research subject is the fourth-semester students of STMIK STIKOM Bali in academic year of 2011/2012. The experimental design used factorial univariate ANOVA $2 \times 2$ designs with the size of sample was 79 students divided into three different classes. Based on the result of the analysis, it can be concluded that the students learning result of the learning style for each dimension was equal. It is also the same with the learning result that was combined learning style type of both dimensions. This shows that the interactive multimedia learning developed has been successful to accommodate the students learning style and therefore learning process with multimedia can be concluded as effective and optimal.
\end{abstract}

\section{Keywords}

Multimedia learning, input learning style dimension, understand learning style dimension, learning result.

\section{INTRODUCTION}

Computer-based learning multimedia (multimedia learning) is a part of e-learning model ${ }^{[1]}$. Nowadays, the technology of multimedia has grown rapidly and increased in use, whether as hardware or software. This makes the techniques and learning practice in traditional class (face-to-face instruction or chalk-and-talk) are able to do in multimedia learning or learning modules ${ }^{[2]}$.

One characteristic of multimedia learning is to facilitate the learners so that they are able to learn on their own ${ }^{[3]}$. Based on that, then we need to focus on the effectiveness of multimedia learning and the learners' learning style in its development. A multimedia learning, on the learning side, can be said to be effective and obtain optimum result if it can integrate the following elements: the objective of learning or learning result, type of contents, learning method, and delivering media ${ }^{[4]}$, also succeeds in accommodating the learners' learning style $\mathrm{e}^{[5][3][1]}$.
This research aims to investigate the effect of different twodimensional learning style (input [visual vs verbal] and understand [sequential vs global]) on the computer based interactive multimedia learning (animation) to the learning results (the ability of the students in applying the objectoriented modeling procedure). Each learning style dimension acts as a factor that its influence needs to be seen. The learning strategy follows Merrill with Component Display Theory $(\mathrm{CDT})^{[7][6]}$ and the presentation strategy follows the Seven Principal Guide Information Presentation in Animation Multimedia Format ${ }^{[8][3]}$.

The Learning process with the interactive multimedia learning is conducted in the class with the research subject is the students of STMIK STIKOM Bali in their fourth semester academic year 2011/2012. The experiment design uses the univariate factorial ANOVA $2 \times 2$ designs with the size of sample were 79 students spreading into 3 classes. It is expected that the influence between those two-dimensions which were connected with the multimedia learning developed and interaction between those dimensions towards the learning result would not be significant. Therefore, it can be stated that the interactive multimedia learning, in the learning process, is effective and can obtain optimum results.

\section{LITERATURE REVIEW}

\subsection{The Learning Result and Learning Strategy}

Generally, learning description identifies three major components: objectives, learning activities, and tests. Objectives state what will be learnt; learning activities are the action where the students participate in obtaining their goals; and tests are events which assess the acquisition degree of purpose.

The purpose or learning result according to Merrill's taxonomy and learning strategy follows a theory known as Component Display Theory (CDT). CDT is a prescription collection which can be used in guiding design and developing learning activities. The degree of applying prescription in a correlation learning activity with degree of purpose acquisition promotion ${ }^{[9][7]}$.

CDT classifies the learning purpose in two dimension or known as Performance-Content (PC) matrix and the Content Type (Table 1). The first dimension is called the ability/performance level, and the second dimension is the type of content dimension. The ability level dimension includes the ability to remember, use (or apply), and find. The content type dimension consists of fact, concept, procedure, and principle. CDT, in its learning strategy, defines a collection of Primary Presentation Format (PPF) (Table 2). For each cell (Table 1) which is a type of purpose/result of 
learning, there is a unique combination of PPF which eventually can promote the purpose type acquisition effectively.

Table 1. Content-Performance Matrix and its examples*

\begin{tabular}{|l|l|l|}
\hline \multirow{2}{*}{} & \multicolumn{2}{|c|}{ Content Type } \\
\cline { 2 - 3 } Use/Apply & $\begin{array}{l}\text { Concept } \\
\text { Classification of } \\
\text { new examples } \\
\text { Choose the valid } \\
\text { signature }\end{array}$ & Lo the procedure \\
\hline * Adopted from the system \\
\hline
\end{tabular}

* Adopted from ${ }^{[6]}$

Note: Table limited according to requirement

Table 2. Primary Presentation Format (PPF)*

\begin{tabular}{|l|l|l|l|l|l|}
\hline $\begin{array}{l}\text { Performan } \\
\text { ce Type }\end{array}$ & \multicolumn{2}{|l|}{ Presentation } & \multicolumn{2}{l|}{ Practice } & \multicolumn{2}{l|}{$\begin{array}{l}\text { Testing } \\
\text { Performance }\end{array}$} \\
\hline Use/Apply & $\begin{array}{l}\text { General } \\
\text { Condition }\end{array}$ & $\begin{array}{l}\text { Example } \\
\text { (some, } \\
\text { new) }\end{array}$ & $\begin{array}{l}\text { Exampl } \\
\text { e (some, } \\
\text { new) }\end{array}$ & Example \\
\hline
\end{tabular}

* Adopted from [6]

\subsection{Multimedia Learning}

Multimedia learning (computer based) is a type of e-learning whose learning is delivered via computer with the learning content (text, graphic, audio, video, animation, etc) restored in CD-ROM or computer file. Learning with multimedia has characteristics as follows ${ }^{[3]}$ : (1) content which are learned is relevant with the purpose of learning; (2) using the learning method as in the examples and exercises/practices to help the learners learn; (3) using the media elements such as words (text) and pictures in delivering the content and learning method; (4) designed for the learners so that they are able to learn on their own (asynchronous learning); and (5) building new knowledge and skill which is connected with the purpose of learning or increasing the organization's performance.

\subsection{Information Presentation Guide in Multimedia Format}

There are seven information presentation guide principles in multimedia format-animation ${ }^{[8][3]}$, they are: (1) Multimedia Principle (learner learns better in animation and narration/audio rather than in narration alone; (2) Spatial Contiguity Principle and Temporal contiguity (learner learns better if the words/text delivered closely to the relevant animation [picture] portion, and portion connected with the narration and animation are delivered simultaneously rather than continuously; (3) Coherence Principle (learner learns better from animation and narration if the irrelevant words/text, sound and picture are removed rather than used; (4) Modality Principle (learner learns better in animation and narration rather than animation and text on the screen); (5) Redundancy Principle (learner learns better in animation and narration rather than in animation, narration and text on the screen); (6) Segmentation/Interactivity Principle and Pertaining (learner learns better if the facility to conducting the essential processing is available to avoid overloading on the cognitive system [the availability of stop, previous and next buttons], and learner learns better if they are given the material orientation session quickly [relevant key concepts] related to the material/content learned before the presentation begins); (7) Personalization Principal (the learner learns better from animation and narration with conversation style rather than formal style).

\subsection{Learning Style}

Learning Style is a choice of how the learner receives information and processes it into a meaningful knowledge. Felder Model is one of learning style model which have impact on academic performance and retention. This model measures the learner's learning style using Index of Learning Styles (ILS) from Felder and Solomon whose reliability and validity have been proven for technical/engineering students ${ }^{[10]}$. This model has four learning style dimensions which are described as follows ${ }^{[11][10]}$ : (1) Information Processing, which is active (the learners learn best through working actively on learning material, by applying and trying; they tend to learn in group), and reflective (the learners tend to think and reflect the learning material; they tend to work alone); (2) Perception, which is sensing (the learners like to learn about facts and concrete learning material), and intuitive (the learners like to learn theoretical/abstract learning material); (3) Input, which is visual (the learners are able to remember best through learning with what they have seen [such as pictures, diagrams, and flow-chart]), and verbal (the learners like to learn learning material through textual representation whether it is in text or narration/sound); and (4) Understand, which is sequential (the learners learn with small increasing step, and therefore has linear advance), and global (the learners tend to absorb learning material almost randomly without seeing the connection [holistic], but when it is felt enough on the learning material, suddenly they have the full picture of the learning material).

An optimum learning can be achieved if there is a match between the learners' learning style with the teachers' teaching style.

\subsection{Learning Style Effect on Learning Result}

In a learning, the existence of different learning styles of the learners can give a significance effect to the learners' learning results (learning becomes ineffective) if these things happen: (1) the teachers' teaching style do not match with half/all the students' learning style ${ }^{[12][5]}$, and (2) in the learning context with multimedia, the multimedia learning is not/less to accommodate different learners' learning style in a match ${ }^{[3]}$.

\section{METHODS}

\subsection{Research Variable and Experiment Design}

This research is quantitive research with quasi-experimantal approach. The purpose is to test the effect of two independent variables on a dependent variable. Both independent variables are input learning style dimension with two kinds of treatment (visual vs verbal learning style), and understand learning style dimension with two kinds of treatment (sequential vs global learning style). The dependent variable is the students' ability in applying procedure. The material wich is learnt is objectoriented modelling. The experimant design is factorial univariat ANOVA $2 \times 2$ experiment

\subsection{Research Subject}

The reserach subject here is the fourth semester students computer system major STMIK STIKOM Bali with the amount of 79 students which spreading in three different classes. The data of the students from both 
factors/groups/learning dimensions and learning style type for each learning style dimension are listed on Table 3.

Table 3. The Amount Of Student Based On The Learning Style Dimension and Type

\begin{tabular}{|c|c|c|c|}
\hline Factor/Dimension & Type & $\mathbf{N}$ & $\%$ \\
\hline \multirow{3}{*}{\begin{tabular}{c} 
Input learning style \\
\cline { 2 - 4 }
\end{tabular}} & Visual & 56 & 71 \\
\cline { 2 - 4 } & Verbal & 23 & 29 \\
\cline { 2 - 4 } & Amount & 79 & 100 \\
\hline \multirow{2}{*}{$\begin{array}{c}\text { Understand learning } \\
\text { style }\end{array}$} & Sequential & 36 & 46 \\
\cline { 2 - 4 } & Global & 43 & 54 \\
\cline { 2 - 4 } & Amount & 79 & 100 \\
\hline
\end{tabular}

Note: $\mathrm{n}=$ amount of students

\subsection{Treatment Design}

The comparative aspects design for both treatment for both learning style dimension on interactive multimedia learning (animation) happen on the same three classes. On those three classes, the students receive the learning through animation multimedia with the same content, but the stdents in each class have different learning style preferences (combination) (visual-sequential, visual-global, verbal-sequential, and verbal-global) in receiving/processing/managing information or content which are presented. All three classes receive the same six multimedia learning modules with different topics for each of them (content adopted and modified from items of object-oriented modelling ${ }^{[13]}$ ); the learning schedule is on the same week for each topic; final test on the same week.

\subsection{Research Variable Measurement}

The dependent variable is measured with final test, by using instrument which is adopted and modified from the model test ${ }^{[14]}$. That instrument can be used to measure the students' ability in appllying procedures of object-oriented modelling. This instrument along with the multimedia learning content have been validated by two validators (experts of information technology field) and it is declared generally good. The validation covers three aspects, they are: (1) the clarity of the content in representing the topics, (2) the match of the content with the learning objective, and (3) the match of assesment instrument in measuring the students' performance (applying procedures). This instrument has reability coefficiency (Alpha Cronbach) of 0.66. Learning Style Index (LSI) is measured by using instrument to measure the learning style according to the Index Learning Style (ILS) from Felder-Soloman ${ }^{[15][10]}$. ILS is an on-line questionnaire which is designed to grade the preferences of 4 dimensional learning style which are active/reflective, sensing/intuitive, visual/verbal, and sequential/global. Each dimension covers 11 question items, therefore there are total of 44 question items. The learning style dimension applied here is input learning style dimension (visual/verbal), and understand learning style (sequential/global).

\subsection{Data Collecting and Analysis Method}

The average description of the learning results score are listed in Table 4 and Table 5. Next, the measuring result data is analysed with univariat variance analysis technique (ANOVA) $2 \times 2$ with the help of SPSS statistic package program. Some statistic assumption that has to be done before conducting the ANOVA analysis technique is data normalization and the homogenity of variance ${ }^{[16]}$.

Table 4. Score Description of The Ability in Applying Procedure Based on Learning Style Type

\begin{tabular}{|c|c|c|c|c|}
\hline \multirow{2}{*}{$\begin{array}{c}\text { Learning } \\
\text { style } \\
\text { dimension }\end{array}$} & \multirow{2}{*}{ Type } & \multicolumn{3}{|c|}{$\begin{array}{c}\text { Ability in applying } \\
\text { procedure }\end{array}$} \\
\cline { 3 - 5 } & & $\mathrm{n}$ & Average & $\begin{array}{c}\text { Deviation } \\
\text { Standard }\end{array}$ \\
\hline \multirow{2}{*}{ Input } & Visual & 56 & 2.59 & 0.08 \\
\cline { 2 - 5 } & Verbal & 23 & 2.45 & 0.13 \\
\hline \multirow{2}{*}{ Understanding } & Sequential & 36 & 2.55 & 0.11 \\
\cline { 2 - 5 } & Global & 43 & 2.48 & 0.11 \\
\hline
\end{tabular}

Note $: \mathrm{n}=$ amount of students

Table 5. Score Description of The Ability in Applying Procedure Based on Learning Style Combination

\begin{tabular}{|c|c|c|c|c|}
\hline \multirow{2}{*}{$\begin{array}{c}\text { Input } \\
\text { learning } \\
\text { style } \\
\text { dimension }\end{array}$} & \multirow{2}{*}{$\begin{array}{c}\text { Understand } \\
\text { learning } \\
\text { style } \\
\text { dimension }\end{array}$} & \multicolumn{3}{|c|}{$\begin{array}{c}\text { Ability in applying } \\
\text { procedure }\end{array}$} \\
\cline { 3 - 5 } & $\mathrm{n}$ & Average & $\begin{array}{c}\text { Deviation } \\
\text { Standard }\end{array}$ \\
\hline \multirow{2}{*}{ Visual } & Sequential & 24 & 2.60 & 0.558 \\
\cline { 2 - 5 } & Global & 32 & 2.57 & 0.660 \\
\hline \multirow{2}{*}{ Verbal } & Sequential & 12 & 2.49 & 0.62 \\
\cline { 2 - 5 } & Global & 11 & 2.40 & 0.49 \\
\hline
\end{tabular}

Note $: \mathrm{n}=$ amount of students

\section{RESULT AND DISCUSSION}

\subsection{Normality Test and Variance Homogenity}

Based on the normality test resullt to dependent variable with the Shapiro-Wilk statistic test, it can be concluded that the assumption of the dependent variable measuring normality result data is fulfilled (Kolmogorov-Smirnov statistic $=0.053$, independent degree $=79$, with significant number $=0.2$ ). So as for the Levene test result for the variance homogeneity test states that that assumption is fulfilled ( $\mathrm{F}$ significant number is 0.685 bigger than $\alpha=0.05$ ).

\subsection{Analysis Result}

The test result of ANOVA $2 \times 2$ the effect of both learning style dimension factors to the learning resultsare stated in Table 6. The analysis result concludes that: there is no significant effect of different learning style type on input learning style dimension (visual vs verbal) to the learning result; there is no significant effect on the different learning style type on understand learning style dimension (sequential vs global) to the learning result; and there is no significant effect of the interaction between both input learning style dimension factor and understand learning style dimension factor to the learning result.

\subsection{Discussion}

4.3.1 Learning Style Effect on Learning Result

The analysis result concludes that there are no significant difference on the students' learning style result in applying 
object-oriented modelling procedure on interactive multimedia learning (animation) between a group of students with input learning style dimension (visual vs verbal) and between a group of students with understand learning style dimension (sequential vs global). This result is in harmony with the results of previous research ${ }^{[17][18][19]}$.

That condition can be happened because the multimedia learning succeed in accomodating the students' learning style preferences (input dimension) through a worthy input between symbol, picture, table, diagram, animation (visual type) and text, narration/sound (verbal type) in learning multimedia presentation. Also for the students' learning style preferences (understand dimension) through the availabilty of facilities which enable the students to study the topics of the material continuously (via next button for the sequential type learning style) and randomly (via pulldown menu button for the global type learning style). This is in accordance to the statement about the effectiveness or ineffectiveness of a class depends on how far the learning strategy accommodate the learners' learning style ${ }^{[3][12]}$.

\subsubsection{Interaction Effect between Both Learning Style Dimension Factors on Learning Result} The analysis result concludes that there is no significant interaction effect between both learning style dimension factors to the students' ability in applying procedures of object-oriented modelling.

The condition can be happened because each learning style dimension factor (input and understand) has no effect on learning result.

\section{CONCLUSION AND SUGGESTION 5.1 Conclusion}

On learning through the computer-based interactive multimedia (learner's control) with animation, the students' learning result (the student's ability in applying objectoriented modelling procedure) whether in students group with input learning style dimension (visual vs verbal) or students group with understand learning style dimension (sequential vs global) is the same. That sameness of learning result also happened for the students group, regardless of the learning style type combination from both learning style dimension (visual-sequential, visual-global, verbal-sequential, verbalglobal).

With the success of that interactive multimedia learning in accommodating the students' learning style, then the learning process can be stated effective and optimum.

\subsection{Suggestion}

Learning with the computer-based interactive multimedia, the accommodation of students' learning style type in its building/development is really needed so that the learning can be conducted effectively and optimum.

\section{ACKNOWLEDGMENTS}

Our gratitude to the management of STMIK STIKOM Bali for the supports and the facilities they have given us during the research and also to the management of dual degree program STMIK-STIKOM Bali Indonesia with Help University College Malaysia.

Table 6. ANOVA 2x2 Test Result for the Effect of Both Learning Style Dimension Factors

Dependent Variable: The Sudent's Ability in Applying Procedure

\begin{tabular}{|l|r|r|r|r|c|}
\hline \multicolumn{1}{|c|}{ Resources } & \multicolumn{1}{|c|}{$\begin{array}{c}\text { Sum of } \\
\text { Squares }\end{array}$} & $\begin{array}{c}\text { Freedom } \\
\text { Degrees }\end{array}$ & $\begin{array}{l}\text { Mean of } \\
\text { Squares }\end{array}$ & F & Significance \\
\hline Model & 511.773 & 4 & 127.943 & 352.169 & 0.000 \\
Input LS (A) & 0.320 & 1 & 0.320 & 0.881 & $0.351^{\mathrm{ns}}$ \\
Understand LS (B) & 0.065 & 1 & 0.065 & 0.180 & $0.673^{\mathrm{ns}}$ \\
A * B & 0.013 & 1 & 0.013 & 0.035 & $0.852^{\mathrm{ns}}$ \\
Error & 27.248 & 75 & 0.363 & & \\
Total & 539.020 & 79 & & & \\
\hline
\end{tabular}

Note: $\mathrm{LS}=$ Learning Style; $\mathrm{ns}=$ non significance

\section{REFERENCES}

[1] Frensen, E. 2007. A Taxonomy of Factors to Promote Quality Web-Supported Learning. E-Learning Journal; 6,3; 351-362.

[2] Ganesan, N. 2009. Rapid Development of Multimedia Instructional Modules for Information Technology Education. Journal of International Technology and Information Management; 18,1: 83-97.

[3] Clark, R.C. \& Mayer, R.E. 2008.E-Learning and The Science Of Instruction. Second Edition. San Francisco: In Print of Wiley.

[4] Clark, R.C. 2008. Developing Technical Training: A Structured Approach for Developing Classroom and Computer-Based Instructional Materials. Third Edition. San Francisco: John Wiley \& Sons, Inc.

[5] Felder, R.M. \& Brent, R. 2009. Effective Teaching: A Workshop. Athlone Institute of Technology, (Online), (http://www.ait.ie/media/athloneit/formsanddocuments/fe
lder-and-brent--Effective-Teaching.pdf). Accessing date July 10, 2012.

[6] Berkove, N. \& Moore, B. 2001. Component Display Theory. In K.L. Medsker \& K.M. Holdsworth. Models and Strategies for Training Design. Silver Spring, MD: International Society for Performance.

[7] Merrill, M.D. 1994. Instructional Design Theory. Englewood Cliffs, New Jersey: Educational Technology Publication.

[8] Mayer, R. E. \& Moreno, R. 2002. Animation As an Aid to Multimedia Learning. Educational Psychology Review; 14,1: 87-99.

[9] Merrill, M.D. 1983. Component Display Theory. In C.M. Reigeluth (Ed.). Instructional design theories and Models (213-246). Hillsdale, New Jersey: Lawrence Erlbaum Associates. 
[10] Litzinger,T.A., Lee, S.H., Wise, J.C. \& Felder, R.M. 2002. A Psychometric Study of the Index of Learning Styles. Journal of Engineering Education; 96,4: 309319.

[11] Graf, S., Viola, S.R., Leo, T. \& Kinshuk. 2007. In-Depth Analysis of the Felder-Silverman Learning Style Dimensions. Journal of Research on Technology in Education; 40,1: 79-93.

[12] Merrill, M.D. 2002. Instructional Goals and Learning Styles: Which takes precedence? In R.A. Reiser \& J.V. Dempsey (Ed.). Trends and Issues in Instructional Design and Technology (99-106). Upper Saddle River, New Jersey: Merrill Prentice Hall.

[13] Sien, V.Y. 2009. BIT 201 Object-Oriented Modelling using UML. Lecture 1-8, lecturing items of Dual-Degree Program. STMIK-STIKOM Bali Denpasar and HELP University College Kualalumpur.

[14] Min, N.S. 2011. BIT 201 Object-Oriented Modelling using UML. Assignment 1, lecturing assignment of Dual-Degree Program. STMIK-STIKOM Bali Denpasar and HELP University College Kualalumpur.
[15] Waras, K. 2003. Pengaruh Model Pembelajaran dan Gaya Belajar terhadap Kecakapan Akademik, Teknikal, dan Pemecahan Masalah Bidang Permesinan. Disertasi. PPS UM Malang.

[16] Hair, J.F. Jr., Black, W.C., Babin, B.J., Anderson, R.E. \& Tatham, R.L. 2006. Multivariate Data Analysis. Sixth Edition. Upper Saddle River, New Jersey: Pearson Education, Inc.

[17] Kozub, R.M. 2010. An ANOVA Analysis Of The Relationships Between Business Student's Learning Styles And Effectiveness Of Web Based Instruction. American Journal

[18] McCann, B.M. 2006. The Relationship between Learning Styles, Learning Environments, and Student Success. Journal of Agricultural Education; 47,3: 14-23.

[19] Yilmaz-Soylu, M. \& Akkoyunlu, B. 2002. The effect of learning styles on achievement in different learning environments. The Turkish Online Journal of Educational Technology; 8,4: 43-50. 